\title{
THE URAL TEXT OF THE RUSSIAN LITERATURE
}

\author{
Marina Ch. Larionova \\ Federal Research Centre The Southern Scientific Centre of Russian Academy of Sciences. \\ Rostov-on-Don, Russia. Email: larionova[at]ssc-ras.ru
}

\begin{abstract}
The article reviews contents, theoretical grounds, and significance for the contemporary philology of a large-scale work of Ural scholars - The History of Literature of the Ural Region (The 19th Century). In the 1920s, the idea of cultural nests - regional cultural centres, which have their own history and traditions, - was formulated in the works by N. K. Piksanov. The idea was followed and further developed by N. P. Antsiferov, who wrote about an attractive and magnetic power of locus, which organizes the cultural space around itself. That was the beginning of regional literature studies. V. N. Toporov and N. E. Mednis introduced the notions of the urban text, local text, and super-text of the Russian literature, which were accepted by the humanities geography (D.N. Zamyatin). Regional philological studies fitted into the frontier discourse smoothly: space and territory began to be perceived and considered as historical and socio-cultural factors. The reviewed book is the Ural text of the Russian literature incorporating literary and journalistic works about this polyethnic macro-region, written by authors biographically and territorially connected with the Large Ural Region; data on bibliography, book publishing and book trade, library management, the history of theatre, etc. The scale of research and the widest coverage of topics and data deserve the highest appraisal and make the work by the Ural colleagues exemplary.
\end{abstract}

\section{Keywords}

The History of Literature of the Ural Region (The 19th Century); cultural nests; local text; regional studies

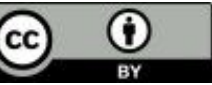

This work is licensed under a Creative Commons «Attribution» 4.0 International License 


\title{
УРАЛЬСКИЙ ТЕКСТ РУССКОЙ ЛИТЕРАТУРЫ
}

\section{Ларионова Марина Ченгаровна \\ Федеральный исследовательский центр Южный научный центр Российской академии наук. Ростов-на-Дону, Россия. Email: larionova[at]ssc-ras.ru}

\begin{abstract}
Аннотация
В статье рассматриваются содержание, теоретические основания и значение для современной филологической науки масштабного труда уральских ученых «История литературы Урала. XIX век», изданного в двух томах под редакцией профессора Е. К. Созиной. В 20-е годы XX века в трудах Н. К. Пиксанова была сформулирована идея «культурных гнезд» - региональных культурных центров, имеющих свою историю и традиции. Ее продолжил Н. П. Анциферов, писавший о притягательной силе локуса, организующего вокруг себя культурное пространство. Так было положено начало литературному краеведению - изучению литературы в связи с историей места, в котором она создавалась и о котором говорила. В работах В. Н. Топорова и Н. Е. Меднис были введены понятия «городской текст», «локальный текст», «сверхтекст» русской литературы, принятые гуманитарной географией (Д. Замятин). Филологическая регионалистика вписалась во фронтирный дискурс: пространство, территория стали восприниматься как исторический и социо-культурный фактор, особое географическое и ментальное образование. Рецензируемая книга представляет «уральский текст» российской литературы и включает в себя художественные и публицистические произведения об этом полиэтничном макрорегионе, созданные писателями, биографически и территориально связанными с Большим Уралом; работы о книжном и библиотечном деле, истории театра и т.д. Масштаб исследования, широчайший охват материала заслуживают самой высокой оценки и делают труд уральских коллег образцовым.
\end{abstract}

\section{Ключевые слова}

«История литературы Урала. XX век»; культурные гнезда; локальный текст; филологическая регионалистика.

Это произведение доступно по лицензии Creative Commons «Attribution» («Атрибуция») 4.0 Всемирная 
В последние десятилетия в филологической науке активизировались исследования, посвященные литературе отдельных территорий. У этих разысканий есть предшественники. Впервые о «провинциальном элементе» русской жизни и литературы заговорил немецкий критик Г. Кёниг, книга которого, названная в русском переводе «Очерки русской литературы», вышла в 1862 году. Н. К. Пиксанов в работах «Два века русской литературы» и «Областные культурные гнезда (историко-краеведный семинар)», (Пиксанов,1923; Пиксанов, 1928) преодолел традиционное для русской культуры и общественной жизни противопоставление «центра» и «периферии», сформулировав идею «культурных гнезд» - региональных культурных центров. Эти «культурные гнезда» хоть и тяготеют к столицам - Москве или Петербургу, - но имеют свое развитие, традиции, историю. Они, по мнению Пиксанова, определяют стилевые, тематические особенности, социальные функции писателей, принадлежащих «гнезду».

О притягательной силе места, локуса, организующего вокруг себя культурное пространство, говорил и Н.П. Анциферов. При этом само место мифологизируется, как это произошло с Петербургом. Место обретает душу, то есть единство географического положения, архитектурного облика, истории, топонимии, духовного наполнения (Анциферов 1991). Так было положено начало литературному краеведению - изучению литературы в связи с историей места, в котором она создавалась и о котором говорила.

Вышедшая в 1983 году работа В.Н. Топорова (Топоров, 2003) произвела большое впечатление на филологов. Понятие «городской текст» вышло далеко за пределы литературного краеведения. Текст понимается как система знаков, исторических, природных и культурных кодов: образов пространства, времени, исторических персонажей, мотивов - всего того, что создает образ территории, не только географической, но и ментальной единицы. Такой текст Н. Е. Меднис назвала «локальным сверхтекстом» (Меднис, 2003). Локальный текст (или, по Меднис, сверхтекст) - одно из основных понятий гуманитарной географии - научного междисциплинарного направления, изучающего географическое пространство с точки зрения региональной идентичности, региональной мифологии (Замятин, 2003). Локальный текст выделяется по пространственному критерию, в его центре - конкретный локус, дающий ему название: «московский текст», «петербургский текст» и пр. Единство локального текста обеспечивается символизацией природных и культурных образов, то есть в роли источников выступает фольклорно-мифологический 
(локальный миф), исторический, антропологический материал то, что образует культурный ландшафт и культурную репутацию территории (Созина, 2010; Щукин, 2010). Кроме образа места, изучается культурный ландшафо, то есть единство материальной и духовной деятельности человека и ее результатов.

Осмысление и структурирование предметного поля понятия «локальный текст» привело к развитию филологической регионалистики - направления в литературоведении, изучающего локальные тексты. В отличие от литературного краеведения филологическая регионалистика «предполагает рассмотрение иного по уровню и объему, расширенного спектра вопросов, включая этническую, национальную, психологическую, культурологическую или концептуальнополитическую проблематику» (Полякова, 2015, сс. 197-198).

Как можно видеть, выявление и изучение локальных текстов, филологическая регионалистика как вектор исследований находятся на острие современного литературоведения и вписываются во фронтирный дискурс, хотя и не являются его ядром: пространство, территория воспринимаются как исторический и социо-культурный фактор, особое географическое и ментальное образование. По словам А.Т. Урушадзе, «фронтир - это способ описания пространства, на котором встречаются и взаимодействуют представители разных культур и социальных традиций» (Как сегодня изучать фронтиры..., 2020, стр. 85).

Книга «История литературы Урала. ХIX век» (История..., 2020) труд титанический (1 440 страниц увеличенного формата), фундаментальный и вполне могущий стать образцовым - является продолжением книги «История литературы Урала. Конец XIV-XVIII в.» (История..,, 2012) и представляет литературу Урала, или уральский текст русской, а точнее - российской, литературы XIX века: художественные и публицистические произведения об этом полиэтничном макрорегионе, созданные писателями, биографически и территориально связанными с Большим Уралом. Российской - потому что, кроме собственно русской литературы, он включает национальные литературы региона: башкирскую, удмурдскую, коми. Наряду с известными именами: П. П. Ершов, В. И. Даль, Д. Н. Мамин-Сибиряк, Т. Г. Шевченко, В.К. Кюхельбекер и др. - исследование включает имена забытых или вовсе не известных широкому кругу филологов и читателей уральских литераторов. Кроме русскоязычных писателей - писателей на национальных языках и их переводчиков. Кроме литературных произведений - периодическую печать Урала, книжное и библиотечное дело, историю театра и драматургии. Особый раздел 
посвящен восприятию Урала в записках путешественников, дневниках, воспоминаниях, в том числе В.А. Жуковского, А.П. Чехова. Это настоящая энциклопедия литературы Урала и об Урале на протяжении столетия.

Основному содержанию книги предшествует обстоятельное предисловие, в котором авторы концептуализируют причины обращения к столь разнообразному материалу и результаты своего труда. Статус Урала в российской истории, отмечают они, «мигрировал от окраинной территории-фронтира до медиального, посреднического региона» (История литературы Урала..., 2020, кн. 1, стр. 25). XIX век на Урале - это не только смена литературных направлений, от классики до модернизма, но и расширение круга читателей, образование «культурных гнезд», становление региональных идентичностей и в конечном счете сплавление их в единый феномен - литературу Урала.

Когда в филологической науке обсуждалась проблема локальных, или городских, региональных текстов, встал вопрос, всякий ли город или регион рождает свой культурный текст. Не будем сейчас углубляться в эту дискуссию: вполне очевидно, что Урал такой текст генерирует и транслирует. Причем, как подчеркивают авторы книги, это вовсе не «провинциальный» текст. Он складывается на огромной многонациональной территории и имеет долгую историю. Особенность Урала еще и в том, что через него пролегали пути из Европы в Азию, то есть это в полном смысле географический центр Евразии и евразийства - настоящий «фронтир».

В рецензируемой книге уральский текст шире, чем административные границы региона. Это связано, во-первых, с динамическими отношениями его центра и периферии, со сменой культурных центров в разное время; во-вторых, с выражением многообразных идентичностей, поскольку народы получали письменность в неодинаковое время; в-третьих, с развитием литературного процесса; наконец, с различными формами взаимодействия уральской литературы с общероссийской и мировой. Все это определило масштаб исследования, которое заслуживает высочайшей оценки и, несомненно, сыграет большую роль в литературоведческой регионалистике и филологической науке в целом.

\section{БЛАГОДАРНОСТИ}

Публикация подготовлена в рамках реализации ГЗ ЮНЦ РАН, № гр. проекта АААА-А19-119011 $190182-8$ 


\section{Список литературы}

Анциферов, Н. П. (1991). Душа Петербурга; Петербург Достоевского; Быль и миф Петербурга. Москва: Книга: Ред.-изд. центр N 2 «Канон».

Басалаева, И. П., Дубман, Э. Л., Мизис, Ю. А., Мильчев, В. И., Сень, Д. В., Урушадзе, А. Т., \& Ходарковский, М. (2020). Как сегодня изучать фронтиры? Дискуссия по статье Д. В. Сеня. Studia Slavica Et Balcanica Petropolitana, (1), 81-105. doi: 10.21638/spbu19.2020.105

Блажес, В. В., \& Созина, Е. К. (Ред.). (2012). История литературы Урала. Конец XIVXVIII в. Москва: Языки славянской культуры.

Замятин, Д. Н. (2003). Гуманитарная география: Пространство и язык географических образов. Санкт-Петербург: Алетейя.

Меднис, Н. Е. (2003). Сверхтексты в русской литературе. Новосибирск: НГПУ.

Пиксанов, Н. К. (1928). Областные культурные гнезда. Москва; Ленинград: Государственное издательство.

Пиксанов, Н. К. (1923). Два века русской литературы. Москва; Петроград: Государственное издательство.

Полякова, Л. В. (2015). Филологическая регионалистика как наука. Bопросы Литераmypbl, (3), 186-201.

Созина, Е. (2010). Локальный текст (1). В И. И. Митин \& Д. Н. Замятин (Ред.), Гуманитарная география: Научный и культурно-просветительский альманах (Выпуск 6, сc. 288-290). Москва: Институт Наследия.

Созина, Е. К. (Ред.). (2020). История литературы Урала. ХІХ век: В 2 книгах. Москва: Издательский Дом ЯСК.

Топоров, В. Н. (2003). Петербургский текст русской литературы: Избранные труды. Санкт-Петербург: «Искусство-СПБ».

Щукин, В. (2010). Локальный текст (2). В И. И. Митин \& Д. Н. Замятин (Ред.), Гуманитарная география: Научный и культурно-просветительский альманах (Выпуск 6, сс. 290-293). Москва: Институт Наследия.

\section{References}

Antsiferov, N. P. (1991). The Soul of St Petersburg; Dostoevsky's St Petersburg; Genesis and Myth of St Petersburg. Moscow: Book: Canon Publishing Centre No. 2. (In Russian).

Basalaeva, I. P., Dubman, E. L., Misis, Y. A., Milchev, V. I., Sen, D. V., Urushadze, A. T., \& Khodarkovsky, M. (2020). How to Study Frontiers Today? Discussion on the Article by D. V. Sen'. Studia Slavica Et Balcanica Petropolitana, (1), 81-105. doi: 10.21638/spbu19.2020.105 (In Russian).

Blages, V. V., \& Sozina, E. K. (Eds.). (2012). History of Ural Literature. The end of the 14th to the 18th century. Moscow: Languages of Slavic Culture. (In Russian). 
Zamyatin, D. N. (2003). Humanitarian Geography: Space and the Language of Geographical Imagery. Saint Petersburg: Aletheia. (In Russian).

Mednis, N. E. (2003). Supertexts in Russian literature. Novosibirsk: NSPU. (In Russian).

Piksanov, N. K. (1928). Regional cultural nests. Moscow; Leningrad: State Publishing House. (In Russian).

Piksanov, N. K. (1923). Two centuries of Russian literature. Moscow; Petrograd: State Publishing House. (In Russian).

Polyakova, L. V. (2015). Philological regionalism as a science. Literature questions, (3), 186201. (In Russian).

Sozina, E. (2010). Local text (1). In I. I. Mitin \& D. N. Zamyatin (Eds.), Humanitarian Geography: A Scientific and Cultural-Educational Almanac (Issue 6, pp. 288-290). Moscow: The Heritage Institute. (In Russian).

Sozina, E. K. (Ed.). (2020). History of the Literature of the Urals. The 19th century: In 2 books. Moscow: YASK Publishing House. (In Russian).

Toporov, V. N. (2003). The Petersburg Text of Russian Literature: Selected Works. Saint Petersburg: Art-SPB. (In Russian).

Shchukin, V. (2010). Local Text (2). n I. I. Mitin \& D. N. Zamyatin (Eds.), Humanitarian Geography: A Scientific and Cultural-Educational Almanac (Issue 6, pp. 290-293). Moscow: The Heritage Institute. (In Russian). 